\title{
Consumption and Standard of Living
}

\section{Cecilia Elena VĂDUVA*}

\begin{tabular}{l}
\hline \multicolumn{1}{c}{ A R T I C L E I N F O } \\
\hline Article history: \\
Accepted June 2016 \\
Available online September 2016 \\
\hline JEL Classification \\
A00, J01, J24 \\
Keywords: \\
Consumption, Living standards, \\
Life
\end{tabular}

\begin{abstract}
A B S T R A C T
Living standards are an indicator mainly economic which can be defined as quantitative aspect of meeting the economic needs of an individual or a community and aims the way how the activity of material and nonmaterial production relates and contributes to meeting the main necessities of life society income. The finality of any kind of economic activity it is the creation of material and spiritual goods which consumed is to increase living standards. Life quality should not be confused with the living standards. Life quality materializes an economic complex process, social and political capture both the premises and the process by which objective and subjective conditions of existence become accessible and positive for humans, living standards target only a sequence of this circuit which represents the only link between the level and quality conditions of social life and the last resultant effect form of living a certain lifestyle. The finality of any kind of economic activity is the creation of material and spiritual goods which consumed lead to the increase living standards. Purchasing power is found in the notions living standards and quality of life.
\end{abstract}

(C) 2016 EAI. All rights reserved.

\section{Introduction}

The dynamics of global demand, the fluctuations of real income are explained by the amount of currency used for buying goods.

Households allocate the disposable income that is the income remained after the reduction of the duties, for the current consumption and for saving and satisfies future consumption needs.

The use the economic goods purchased by the households, other economic agents and public administrations to satisfy a personal or collective need, use involving the destruction of goods defines the consumption.

The consumption of households is studied with the help of family budgets. The family budget is an evidence system by which it is usually systematically and chronologically registered the income after its nature and the consumption expenses on different categories on one-year period. The budgets are elaborated on different categories and family representative types.

Wellbeing is an essential criterion of assessment for the efficient functioning of a society and is based on the quality concept of life synthesizing all conditions that ensure the integrity and development of human life, meeting the criteria and material and spiritual aspirations at a high quality level.

The life quality should not be confused with the standard of living that is the link between the level and quality of social life conditions, the last resultant under the form of effect. Life quality aims to a complex of economic, social and political processes, approaching both the premises and the process by which the objective and subjective conditions of existence become accessible and man's positions as the resultant of this process, the standard of living aims only a sequence of this criterion.

The standard of living may be defined by the degree of satisfaction of the material and spiritual needs of the population of a country, of certain social groups or persons in the conditions given by the production development.

The standard of living shows the way in which the material and immaterial production activity reports and contributes to satisfy the main necessities of life of the member of society.

Within the general report between production and consumption, first place belongs to production because consumption has no object without the created product; the volume, quality and way to produce determines volume, variety and type of consumption. The relationship between the two moments of reproduction must be viewed in double sense, one that is established between means (production) and purpose (consumption) on the one hand, and between two moments of reproduction which reciprocally interrelate, on the other hand. If the production makes the consumption and the consumption permanently fixes the objective of the production as necessity, stimulus, and purpose.

The purpose of any kind of economic activity is the creation of material and spiritual goods which lead to the increase of the standard of living. 
The structure of expenses for personal consumption under the aspect of destinations differs from one country to another and from one period to another, presents certain regularity depending on income. The income available to housekeeping are limited, the consumer selects the necessities to be satisfied and compares the utility to goods being preoccupied to ensure the maximum of satisfaction. According to the specific law for the distribution of consumption expenditure, reaching the maximum consumption satisfaction takes place under the conditions were the final utilities of the last consumed goods from each group, each category of expenses destined to consumption are equal. The evolution of expenses for consumption appreciated based on the family budgets highlights the following tendencies: expenses for food consumption in the context of structural diversification and improving the quality increase in a smaller measure than the income and reduce their share; expenses with clothing, shoes and accessories follow the same dynamics as the group of expenses for food; expenditure with services.

\section{Small conclusions on the standard of living - an expression of the quality of life in Romania and the UE}

The human condition, lifestyle, social status, culture, values and aspirations are sky concept addressed in the context of standard of living.

The current conditions of life in our country and in particular the standard of living can be understood by analyzing the changes taking place in their premises complex causes and influences. Reality shows that the living standard in Romania is covered in an extremely different depending on the size of the monthly family income (annual) and the size of each family, in correlation with consumer spending on food structured, non-food and services.

This moment in Romania in food prices represent two thirds of the EU average, approaching even the average cheese, milk and eggs, while the standard of living is half that of Europe. According to Eurostat data communicated by Romania came in $2014-57 \%$ of the average EU standard of living, according indicator of actual individual consumption (AIC abbreviated in English)

In variant known for measuring the standard of living, which consists of GDP per capita at purchasing power parity standard, we have located $55 \%$ of the EU average.

Effective individual consumption of (AIC abbreviated in English) more accurately reflect the welfare of a citizen of a particular country than GDP per capita.

GDP per inhabitant is based on goods and services purchased and paid by a household. Instead, AIC is calculated based on goods and services actually consumed by individuals, without regard to the fact that they were contracted and paid by households, government or nonprofit organizations. Therefore, it is preferable for international comparisons and better reflect the standard of living.

The differences resulting from the fact that the share of payments made directly to households for valuable services such as health and education, differs substantially from country to country.

From the sources analyzed shows that Romania won the first place in the European Union the production of sunflower, the download speed Internet and the growth rate of production of cars - these are just three areas in which Romania receives top marks compared to other EU states.

On the other side, Romania occupies the peak position in terms of expenditure they make for construction of highways: one kilometer of motorway Romanian state managed to spend 23 million euro, while the Bulgarian state has a cost two mil. euro for each kilometer of highway built - this is the lowest cost to the member states of the EU.

Analyzing these things is noted that the another worrying statistics but reflect the standard of living the real population is the share of food in total expenditure of households: one-third of the monthly expenses of a family in Romania is represented by food, drink and cigarettes, while Austrians, for instance, this expenditure represents more than $13 \%$ of consumption of a household budget.

Analyzing these things is noted that the another worrying statistics but reflect the standard of living the real population is the share of food in total expenditure of households: one-third of the monthly expenses of a family in Romania is represented by food, drink and cigarettes, while Austrians, for instance, this expenditure represents more than $13 \%$ of consumption of a household budget.

Is paradoxically, although he pays best builders, Romania is the second lowest in Europe after Bulgaria concerning the motorway network (with only 645 kilometers by).

After two increases, which took place in 2014, the gross minimum wage in Romania reached 1,050 lei (232 euros), and on 1 May 2016, the minimum income could reach 1,250 lei (276 euros) . But even in this condition Romanians income much lower than the Europeans. Chapter gross minimum wage, only Bulgarians are worse than us because they get to earn monthly 184 euros, and the level at which they are paid employees the lowest wages in Romania is seven times lower than they are employees of French who the lowest salaries.

In Romania, low wages are reflected in the salaries of those who should be among the highest paid employees: salaries of teachers and doctors are Romanian lowest in nearly all Member States of the European Union.

In matters of European funds statistics show that, seven years after joining the EU, Romania has managed to attract only a third of the nearly 20 billion provided in 2007-2013. Poland, for example, the only 
country to avoid recession in all the years of the financial crisis, had an absorption rate of $60 \%$ of the Structural Funds.

Although Romania was noticed by having the highest speed data download on the Internet in Europe, but it is worse than other European countries Chapter share of households with high-speed fixed Internet. If Belgium and the Netherlands share is over $97 \%$ in Romania only $63 \%$ of households have high-speed fixed Internet. Which should be improved in the next period.

Regarding industry rankings, analyzed data show that Romania is ranked in the top 16 largest steel producers in Europe, with a production of 3.2 million tonnes of crude steel.

However we own places in the top European leader in terms of wine production, cement or shoes. Last year Romania ranked 6 in the European Union in terms of wine production, from countries such as Italy, Spain, France, Germany and Portugal. Although spending money on shoes compared to other states, Romanian employees in this industry have managed to place 4th in Europe Romania regarding the most expensive shoes produced in local factories, after Italy, Portugal and France.

While not sit very well compared to the other Member somewhat surprisingly, our country registered a decrease from the 2013 actual consumption, despite growth pretty good. Instead, I returned in 2014 with the highest increase recorded in the bloc. and the benefits granted in 2015 and those planned for 2016 are likely to take us over the $60 \%$ threshold at AIC before the GDP to reach this quota. The question remains whether the standard of living should be above this threshold (theoretically recommended) to adopt the euro or the result of the economy.

In conclusion, we can say that the concept of standard of living can be viewed on the one hand, from a subjective perspective, on the other hand, from an objective perspective, with its pragmatic implications in all spheres of economic and social activity. The way we choose to live depends on the wishes and aspirations of each in relation to a set of conditions and possibilities (resources) created in the context of a society.

Though it Romania seems a rather poor country can say that during the last manifestation of the effects of the global economic crisis, Romania has improved the standard of living indicator of $49 \%$ of the EU average to $54 \%$ of this average. The down payment of five per cent, placing Romania in this regard in sixth place, tied with Austria. Noting that, despite appearances, Eurostat data show that the standard of living has not decreased in any year in Romania during the crisis.

The developments in some European countries allow conclusions regarding changes in standards of living relative depending on economic and social policies adopted. One can notice the performance of Germany, the locomotive of economic recovery, large economy that has significantly improved the relative position and scored the most significant increase, although only occupies fourth place.

Table 1. Top-level increases living in the EU, from 2008 to 2013,2014

\begin{tabular}{lll}
\hline & COUNTRY & GROWTH (\%) \\
\hline 1. & Polonia & $+12 \%$ \\
2. & Lituania & $+10 \%$ \\
3. & Letonia & $+9 \%$ \\
4. & Germania & $+8 \%$ \\
5. & Malta & $+6 \%$ \\
6-7. & Romania & $+5 \%$ \\
& Austria & $+5 \%$ \\
\hline
\end{tabular}

Source: EUROSTAT

Poland, Lithuania and Latvia, as well as Austria, economic challenges and managed well, benefiting from the driving effect of Germany, marked a pronounced increase in living standards. Remember, the Baltic economies (more elastic through the small size and aided by northern neighbors) had first period kickback who quickly restructured bases that have started economic recovery.

Countries with which Romania has signed the best that evolving standards of living were Bulgaria and Slovakia, which are performing very close, with an increase of four percentage points each. Slovakia exceeded thus a country that has come down from a higher standard of living than Greece $(-18 \%)$. It is a hope and a warning for a possible access conditions in the euro area economy would not be able to face competition in the medium and long term.

Table 2. Top of decreases in living standards in the EU, from 2008 to 2013.2014

\begin{tabular}{lll}
\hline & COUNTRY & DECREASE (\%) \\
\hline 1. & Grecia & $-18 \%$ \\
$\mathbf{2 .}$ & Cipru & $-13 \%$ \\
$\mathbf{3 - 4}$ & Spania & $-8 \%$ \\
& Slovenia & $-8 \%$ \\
$\mathbf{5 - 6 .}$ & Olanda & $-7 \%$ \\
\hline
\end{tabular}




\begin{tabular}{ll|l}
\hline & Finlanda & $-7 \%$ \\
7. & Italia & $-6 \%$ \\
8. & Irlanda & $-5 \%$ \\
\hline
\end{tabular}

Source: EUROSTAT

All these considerations is particularly significant in the light of Romania's stated objective, which is to join the Eurozone in 2019. Without being an explicit requirement beyond the exaggerations and Hungarian (who see a need for $90 \%$ of EU average) benchmark minimal this accession as a standard of living $60 \%$ of that recorded in the Union.

Recovering the standard of living six percent of GDP expressed in purchasing power parity standard in the next five years remains problematic and the timing of restructuring very closely. In this context, price stability will become at least as important as GDP growth, that inflation does not erode economic advance.

In an underdeveloped country, there is a problem of survival, to ensure the minimum necessary for a civilized existence.

In a developed economy, converting necessities, reversing the natural production-consumption relation and distorting the finality of consumption are current problems; if we take into account the sense and content of the human needs whose cover has to be ensured by production; advertising and everything related to it can make of the consumable good a fetish without reporting it to a real necessity. The presence of a problem like that of false and true necessities may be constant if we think and we are obliged to do it, to the possibilities that production offers.

For a certain period of time, on the overall of the national economy, the consumption cannot exceed what was produced and due to reasons related to the need for maintaining reserve stocks and ensuring that there was not consumed all that was produced, a certain share of the product being kept under reserve.

The unlimited character of certain needs and the conjectural possibility of pushing the threshold limit may turn and switch to the consumerist attitudes.

The production-consumption equation obliges to accept the idea of limits that reality or lack of resources imposes to offer.

The purchasing power is found in the reasons of the standard of living and quality of life.

The standard of living is an economic indicator that may be defined as representing the quantitative aspect to satisfy the economic necessities of an individual or of a collectivity. The standard of living has the following ratings: it exclusively refers to the economic needs of the individual or collectivity; it exclusively refers to the quantitative dimension of the product to satisfy these economic needs; it is completely quantifiable; it is a relation between the economic needs and the capacity of the individual or society to satisfy.

The standard of living may be established by the legal or political standards and we talk about a normal standard of living, and also a standard of living that is effectively achieved by an individual or collectivity and then we talk about a current standard of living, an expected anticipated level and we talk about a desirable type of standard of living.

The measurement of the standard of living is made with the help of the economic indicators of consumption by determining as average the consumption of goods and services per inhabitant.

Highlighting the standard of living requires a comparison, a reference point. This reference point may be: the normal standard of living and it is determined the deviation of the current standard of living compared to normal one; a previous standard of the effective standard of living and it is determined the dynamics of the effective standard of living between the two analyzed time points; a desirable standard of the standard of living and it is determined the expectation horizon of the individual or collectivity from the point of view of the standard of living to be reached.

The standard of living is a resultant of the social finality of economic growth; the social finality of the economic growth is the transformation of the abstract economic results of the economic growth in effects on fulfilling the personality of individual or society. The social finality of the economic growth aims to satisfy the human needs in general. The standard of living refers to the first category of needs, those of subsistence. The most important indicator of the standard of living is the real income.

Life quality is a larger concept than that of the standard of living containing the qualitative dimensions besides the quantitative aspects. The standard of living mainly refers to the individual and the life quality also looks at the society as a whole being able to define it as the whole of the conditions and spheres making up the full life of man.

The economic efficiency does not always involve the social efficiency, and the economic rationality does not always involve the social rationality.

\section{Conclusions}

The consumption credit is the financial instrument that influences both the offer and the demand of material goods within the market economy. 
The differential evolution of price structure will favor the change of the behavior of economic agents and population in the direction of saving and accumulation. A great attention will be paid to the normalization of consumption-saving-investments which means an increase of the share of saving in incomes.

The changes in the structure of the consumption expenditure from the family budgets generated by the price evolution induce a discrepancy between the inflation rates as a measure of the overall development of prices for the bought goods and the tariffs for services used directly by population and the inflation rate as an expression of life cost with direct impact on the perception of inflation by population.

\section{Bibliography}

1. Băbăilă I., Silagi Gr, Duţă A., Imbriescu I., "Microeconomics", Mirton Publishing House, Timişoara, 2013.

2. Moșteanu T., "Consumption in the economic theory", Mirton Publishing House, Timişoara, 2014.

3. Ignat I, Pohoaţă I, Luţac Gh., Pascariu S., "Political economy", Economica Publishing House, Bucharest, 2012.

4. http://www.capital.ro

5. http://www.zf.ro

6. http://ec.europa.eu/eurostat

7. http://www.mmuncii.ro

8. www.asfromania.ro/.../Rapoarte 